\title{
Does The Gold Olympic Medal Affect Financing of Sports Federations in the Czech Republic?
}

\section{Má v České republice zlatá olympijská medaile vliv na financování sportovního svazu?}

\author{
Jiri Kotab
}

University of Economics, Prague

\begin{abstract}
:
The article considers funding of Czech national sports federations aimed at representing the Czech Republic at major international sporting events in those sports that are successful in Olympic Games. In the initial part of the article the account of the medals earned by Czech athletes at Summer and Winter Olympic Games from 1996 to 2012 is listed. Next, the model of redistribution of government financial sources to various sports federations from 1999 to 2010 is given. Thirdly the funding of successful sports federations (namely athletics, canoeing, sport shooting, skiing and speed skating) in order to represent Czech Republic at major international sporting events is analyzed. Finally, the conclusion of the most important factors that influence the particular amount of support that flows from the Czech government to single sports federations is done.
\end{abstract}

\section{Abstrakt:}

Článek se zabývá financováním sportovní reprezentace České republiky v olympijsky úspěšných sportech. $V$ úvodu prináší prehled olympijských medailisti̊ z České republiky od roku 1996 do roku 2012. V dalši části je popsán model redistribuce státních prostředkư na sportovní reprezentaci. Třetí část se zabývá analýzou financování jednotlivých sportovních svazů (atletika, kanoistika, sportovní střelba, lyžování a rychlobrusleni) za účelem reprezentace České republiky na vrcholných mezinárodních sportovních akcích. V závěru jsou popsány hlavni faktory, které ovlivňuji výši prostředků, přidělovaných ve prospěch jednotlivých sportovních svazů. Klíčová slova: Obezita, Kognitivně behaviorální terapie, BMI, pohybová aktivita

Key words: Olympic medal, Sport, Financing, Sports Federation

Klíčová slova: Olympijská medaile, sport, financování, sportovní svaz

This research article is the outcome of the research project „Vliv sportovního úspěchu na ekonomiku sportu” registered at IGA VŠE under evidence number F3/10/2013

\section{INTRODUCTION}

The Olympic Games rank among the most popular and prestigious sports events in the world. For most athletes they represent the most important sports event in the four years period. Olympic Games can affect one's sporting career in both negative and positive way. Athletes who gain the gold Olympic medal turn celebrities especially in small countries, such as the Czech Republic. Olympic medalists become famous, get new sponsor contracts, increase their brand value and become idols especially for those young people who are sports fans. The main research question of the paper remains whether or not the sports federations can utilize sporting success of their athletes. Research question deals with the fact that there is a limited amount of government generated money for support of national teams to represent the Czech Republic at international sporting events, which is spread into various sports. Do the sports that generate the gold Olympic medalist gain higher share of revenue of government generated money which flow into the sport? Is it possible to find relationship between 
Gold Olympic medal and share of the government money for particular sports federation?

Theory is concerning government financing of sport and the survey of government models funding of sports in EU countries (Andreff and Szymanski, 2006). Theory also presents practice of redistribution of public money to particular sports federations in the Czech Republic. According to the theory, the redistribution system adopted by the government should favor successful Olympic sports.

\section{METHODS AND THEORY}

Recent gold Olympic medals won by the Czech Republic in the Olympic Games since 2000 are taken into the consideration. Particular sports (successful for the Czech Republic) are analyzed in the study. The data about Olympic medals are taken from the Czech Olympic Committee (ČOV).

Consequently the model of redistribution of government money that is given to national sports federations for the representation purposes is described. The model of the redistribution is published annually in documents entitled "The principles of the program for sports federation government support". It is published by the Ministry of Education, Youth and Sports (MŠMT) which is responsible for the redistribution of that part of government money in the Czech Republic which flows in sports. The model is relatively stable so that the data can be compared.

After describing the model of redistribution of government money for national sport federations the evidence of redistribution for five sports (those successful in Olympic Games history) is given. The evidence comes from annually published documents "Funding of the national sports federations". In these documents (published by Ministry of Education, Youth and Sports (MŠMT)) two figures are important. The first one shows standing of the particular sport in the TOP ranking of sports in the Czech Republic while the second important figure is the actual sum of money appropriated each year to particular sport federation by the government.

All the data as given above create the dataset for qualitative analysis which tracks money from government that flow to particular sport federations in comparison with successes of the particular sport at the Olympic Games (as the most important sporting event in the World).

Results of the research show how sporting success of a particular sport at the Olympic Games affects financing of representation of a national team at international sporting events. The article answers the main questions: is the Gold Olympic medal important for the sports federation and what are other key factors which influence the financing of the sport?

HISTORY OF CZECH MEDALS AT OLYMPIC GAMES FROM 1996 TO 2012

\section{Summer Olympic Games}

\begin{tabular}{|c|c|c|c|c|}
\hline Olympics & Medal & Athlete & Sport & Discipline \\
\hline \multirow{11}{*}{$\begin{array}{c}1996 \\
\text { Summer } \\
\text { Olympic } \\
\text { Games in } \\
\text { Atlanta }\end{array}$} & \multirow{4}{*}{ Gold } & Martin Doktor & Canoeing & C1 500m men \\
\hline & & Martin Doktor & Canoeing & C1 $1000 \mathrm{~m}$ men \\
\hline & & Stepanka Hilgertova & Canoeing & K1 Canoe Slalom women \\
\hline & & Jan Zelezny & Athletics & Javelin men \\
\hline & \multirow{3}{*}{ Silver } & Czech team & Tennis & Doubles women \\
\hline & & Czech team & Canoeing & C2 Canoe Slalom men \\
\hline & & Lukas Pollert & Canoeing & C1 Canoe Slalom men \\
\hline & \multirow{4}{*}{ Bronze } & Jana Novotna & Tennis & Singles ladies \\
\hline & & Tomas Dvorak & Athletics & decathlon \\
\hline & & Sarka Kasparkova & Athletics & triple jump women \\
\hline & & Miroslav Janus & Shooting & Men's 50m Running Target \\
\hline
\end{tabular}




\begin{tabular}{|c|c|c|c|c|}
\hline \multirow{6}{*}{$\begin{array}{c}2000 \\
\text { Summer } \\
\text { Olympic } \\
\text { Games in } \\
\text { Sydney }\end{array}$} & \multirow{2}{*}{ Gold } & Stepanka Hilgertova & Canoeing & K1 Canoe Slalom women \\
\hline & & Jan Zelezny & Athletics & Men's javelin \\
\hline & \multirow[t]{2}{*}{ Silver } & $\begin{array}{l}\text { Rudolf Kraj } \\
\text { Petr Malek }\end{array}$ & $\begin{array}{l}\text { Boxing } \\
\text { Shooting }\end{array}$ & $\begin{array}{l}\text { Men's } 75 \text { - } 81 \mathrm{~kg} \text { (light- } \\
\text { heavyweight) } \\
\text { Men's Skeet (125 Targets) }\end{array}$ \\
\hline & & Roman Sebrle & Athletics & decathlon \\
\hline & \multirow{2}{*}{ Bronze } & Martin Tenk & Shooting & Men's 50m Pistol (60 Shots) \\
\hline & & Czech team & Canoeing & C2 Canoe Slalom men \\
\hline \multirow{9}{*}{$\begin{array}{c}2004 \\
\text { Summer } \\
\text { Olympic } \\
\text { Games in } \\
\text { Athens }\end{array}$} & Gold & Roman Sebrle & Athletics & decathlon \\
\hline & \multirow{3}{*}{ Silver } & $\begin{array}{l}\text { Lenka Hykova- } \\
\text { Maruskova }\end{array}$ & Shooting & $\begin{array}{l}\text { Women's 25m Pistol (30+30 } \\
\text { Shots) }\end{array}$ \\
\hline & & Lenka Smidova & Sailing & $\begin{array}{l}\text { Women's Single-handed Dinghy } \\
\text { (Europe) }\end{array}$ \\
\hline & & Czech Team & Rowing & $\begin{array}{l}\text { Men's Quadruple Sculls Without } \\
\text { Coxsw }\end{array}$ \\
\hline & \multirow{5}{*}{ Bronze } & Jaroslav Baba & Athletics & Men's high jump \\
\hline & & $\begin{array}{l}\text { Vera Cechlova- } \\
\text { Pospisilova }\end{array}$ & Athletics & Women's discus throw \\
\hline & & Libor Capalini & $\begin{array}{l}\text { Modern } \\
\text { Pentathlon }\end{array}$ & Men's Individual Competition \\
\hline & & $\begin{array}{l}\text { Katerina Kurkova- } \\
\text { Emmons }\end{array}$ & Shooting & $\begin{array}{l}\text { Women's 10m Air Rifle (40 } \\
\text { Shots) }\end{array}$ \\
\hline & & Czech team & Canoeing & C2 Canoe Slalom men \\
\hline \multirow{3}{*}{$\begin{array}{c}2008 \\
\text { Summer } \\
\text { Olympic } \\
\text { Games in }\end{array}$} & \multirow{3}{*}{ Gold } & Barbora Spotakova & Athletics & Women's javelin \\
\hline & & $\begin{array}{l}\text { Katerina Kurkova- } \\
\text { Emmons }\end{array}$ & Shooting & $\begin{array}{l}\text { Women's 10m Air Rifle (40 } \\
\text { Shots) }\end{array}$ \\
\hline & & David Kostelecky & Shooting & Men's Trap (125 Targets) \\
\hline \multirow[t]{3}{*}{ Beijing } & \multirow{3}{*}{ Silver } & $\begin{array}{l}\text { Katerina Kurkova- } \\
\text { Emmons }\end{array}$ & Shooting & $\begin{array}{l}\text { Women's } 50 \mathrm{~m} \text { Rifle } 3 \text { Positions } \\
(3 \times 20 \text { Shots })\end{array}$ \\
\hline & & Ondrej Synek & Rowing & Men's Single Sculls (1x) \\
\hline & & Czech team & Canoeing & C2 Canoe Slalom men \\
\hline \multirow{10}{*}{$\begin{array}{c}2012 \\
\text { Summer } \\
\text { Olympic } \\
\text { Games in } \\
\text { London }\end{array}$} & \multirow{4}{*}{ Gold } & Barbora Spotakova & Athletics & Women's javelin \\
\hline & & Miroslava Knapkova & Rowing & Women's Single Sculls (1x) \\
\hline & & David Svoboda & $\begin{array}{l}\text { Modern } \\
\text { Pentathlon }\end{array}$ & Men's Individual Competition \\
\hline & & Jaroslav Kulhavy & $\begin{array}{l}\text { Cycling } \\
\text { Mountain } \\
\text { Bike } \\
\end{array}$ & Men's Cross-country \\
\hline & \multirow{3}{*}{ Silver } & Vavrinec Hradilek & Canoeing & K1 Canoe Slalom men \\
\hline & & Ondrej Synek & Rowing & Men's Single Sculls (1x) \\
\hline & & Czech team & Tennis & Doubles women \\
\hline & \multirow{3}{*}{ Bronze } & Zuzana Hejnova & Athletics & 400m women hurdles \\
\hline & & Adela Sykorova & Shooting & Women's 50m Rifle 3 Positions \\
\hline & & Czech Team & Canoeing & Men's K-4 1000m (kayak Four) \\
\hline
\end{tabular}

Source: Author from www.olympic.cz 


\section{Winter Olympic Games}

\section{Winter Olympic Games in Nagano}

Czech Olympic team gained one gold Olympic medal as the team of Czech ice-hockey players won the Olympic tournament.

Silver and bronze medals were earned by Katerina Neumannova in two races ( $5 \mathrm{~km}$ classical style and combination race) in cross country skiing.

\section{Winter Olympic Games in Salt Lake City}

There was one gold Olympic medal asset for the Czech Republic. The medal was won by Ales Valenta in acrobatic ski jumping.

Two silver medals gained Czech Olympic team were due to the second places of Katerina Neumannova in two races $(15 \mathrm{~km}$ freestyle and combination race) in cross country skiing.

\section{Winter Olympic Games in Torino}

Torino was another single gold Olympic event for the Czech Republic. Katerina Neumannova won 30 kilometers cross country freestyle race in Nordic skiing.

Also, Katerina Neumannova added another silver Olympic medal in skiatlon as well as Lukas Bauer in 15 kilometer classical style race in cross country skiing. Team of ice-hockey players earned bronze medals in the Olympic tournament.

\section{Winter Olympic Games in Vancouver}

In Vancouver Winter Olympic Games Czech Olympic team earned two gold medals thanks to Martina Sablikova who won two races $(3000 \mathrm{~m}$ and $5000 \mathrm{~m})$ in speed skating. She also won bronze medal in one discipline $(1500 \mathrm{~m})$. Two bronze medals were earned in cross country skiing - one in men relay and one by Lukas Bauer. Last bronze medal was gained by Sarka Strachova Zahrobska in slalom in Alpine skiing.

\section{REDISTRIBUTION OF GOVERNMENT MONEY FOR NATIONAL SPORT FEDERATIONS - MODEL}

National sports teams (through national sports federations) are funded by money from public budgets in the Czech Republic according to the Czech laws. Ministry of Education, Youth and Sports in the Czech Republic is responsible for the redistribution of government money in particular sport federations. Their officials publish annually documents: "The principles of the program for sport federation government support". General rules of redistribution of government support are presented there.

Total amount of money known as the contribution to the Czech Republic representation at international sporting events for each sport federation is divided into three parts according to the following principles:

1. $20 \%$ for the preparation of athletes.

2. $30 \%$ for the participation of athletes at sporting events.

3. $50 \%$ based on sporting success at major international sporting events last three years.

According to the principles the support of particular national sports teams is differentiated so that each sports federation gains different amount of money for the representation of the Czech Republic at international events. According to those principles the ranking of sport federations is created. This ranking is called TOP Ranking.

Sports federations, sports organizations and sporting events are divided into groups with different support. Each supported group thus receives different contribution. Sporting events were added on the list of supported activities in 2009 and the contribution is dependent on the evaluation of experts. Specific organizations like Czech Olympic Committee, Anti-doping agency, University sports etc. are also part of the overall contribution which flows into sport. Their contribution from government is subject to decision of expert group. Sports federations are divided into four groups. The first three groups share one budget according to the standings in TOP ranking. The fourth group of sports federations (the least important for the Czech Republic) gets fixed fee payments. Throughout the years there were only slight differences between numbers of sports federations in each supported group and ratios of money from overall budget for each group. In the following table the division of supported groups of sport federations and organizations among 1999 and 2012 is shown. 
Table 1: Number of sports federations in supported groups and ratios of contribution

\begin{tabular}{|c|c|c|c|c|c|c|}
\hline Group & $\begin{array}{l}\text { Position in TOP } \\
\text { Number of } \\
\text { sports }\end{array}$ & $\begin{array}{c}\text { Ratio of } \\
\text { overall } \\
\text { contribution }\end{array}$ & $\begin{array}{l}\text { Position in } \\
\text { TOP Number } \\
\text { of sports }\end{array}$ & $\begin{array}{c}\text { Ratio of } \\
\text { overall } \\
\text { contribution }\end{array}$ & $\begin{array}{l}\text { Position in } \\
\text { TOP Number } \\
\text { of sports }\end{array}$ & $\begin{array}{c}\text { Ratio of } \\
\text { overall } \\
\text { contribution }\end{array}$ \\
\hline & \multicolumn{2}{|c|}{ 1999-2002 } & \multicolumn{2}{|c|}{$2003-2008$} & \multicolumn{2}{|c|}{$2009-2012$} \\
\hline 1 & $1-10$ & $55 \%$ & $1-11$ & $53 \%$ & $1-12$ & $55 \%$ \\
\hline 2 & $11-60$ & $42 \%$ & $11-60$ & $45 \%$ & $13-60$ & $43 \%$ \\
\hline 3 & $61-80$ & $3 \%$ & $61-80$ & $2 \%$ & $61-80$ & $2 \%$ \\
\hline 4 & 81 and more & Fixed fee & 81 and more & Fixed fee & 81 and more & Fixed fee \\
\hline 5 & $\begin{array}{c}\text { Specific } \\
\text { organizations } \\
\text { (NOC...) }\end{array}$ & $\begin{array}{l}\text { According to } \\
\text { the } \\
\text { endorsement }\end{array}$ & $\begin{array}{c}\text { Specific } \\
\text { organizations } \\
\text { (NOC...) }\end{array}$ & $\begin{array}{l}\text { According to } \\
\text { the } \\
\text { endorsement }\end{array}$ & $\begin{array}{c}\text { Specific } \\
\text { organizations } \\
\text { (NOC...) }\end{array}$ & $\begin{array}{l}\text { According to } \\
\text { the } \\
\text { endorsement }\end{array}$ \\
\hline 6 & N/A & & N/A & & $\begin{array}{l}\text { Sporting } \\
\text { Events }\end{array}$ & $\begin{array}{l}\text { According to } \\
\text { the } \\
\text { endorsement }\end{array}$ \\
\hline
\end{tabular}

Sources: Annual Principles of the program for sports federation government support

Subsequently the criteria for assessment of standings for particular sports federation each year in TOP ranking are:

- Final results of athletes at the Olympic Games, World Championships, European Championships, World Junior Championships and European Junior Championships.

- Evaluation of competition of particular sport - number of athletes participating, in particular competition.

- Evaluation for share of team members in particular sports - for sports which aren't individual.

- Evaluation of international popularity - the number of members (national sport federations) in particular international sport federation.

- Technical coefficient - previously it was parameter of national popularity however since 2006 there are more factors that affect the result.

At the end of the principles there is stated that gained points from these calculations are only component values for assessment of final and objective financial contributions of government money for representation of Czech Republic at international sporting events.

\section{Results and discussion}

\section{Redistribution of Government Money for National Sport Federations - Evidence and Analysis}

Sport federations that are (according to gained gold Olympic medals between 2000 and 2008) analyzed:

- Athletics

- $\quad$ Canoeing (includes Canoe slalom and Canoe sprint)

- $\quad$ Sport shooting

- $\quad$ Skiing (includes Nordic skiing, Alpine skiing, acrobatic skiing etc.)

- $\quad$ Speed skating

Analysis is divided into three parts:

1. Standings of sports federations in TOP Ranking

2. Overall contributions to sports federations

3. Analyses of particular sports federations financing 


\section{Overall contributions to sports federations}

In the following table the contributions for selected national sport federations aimed at representing the Czech Republic at international sporting events from 1999 to 2012 can be found.

Table 3: Redistribution of government money for national sport federations

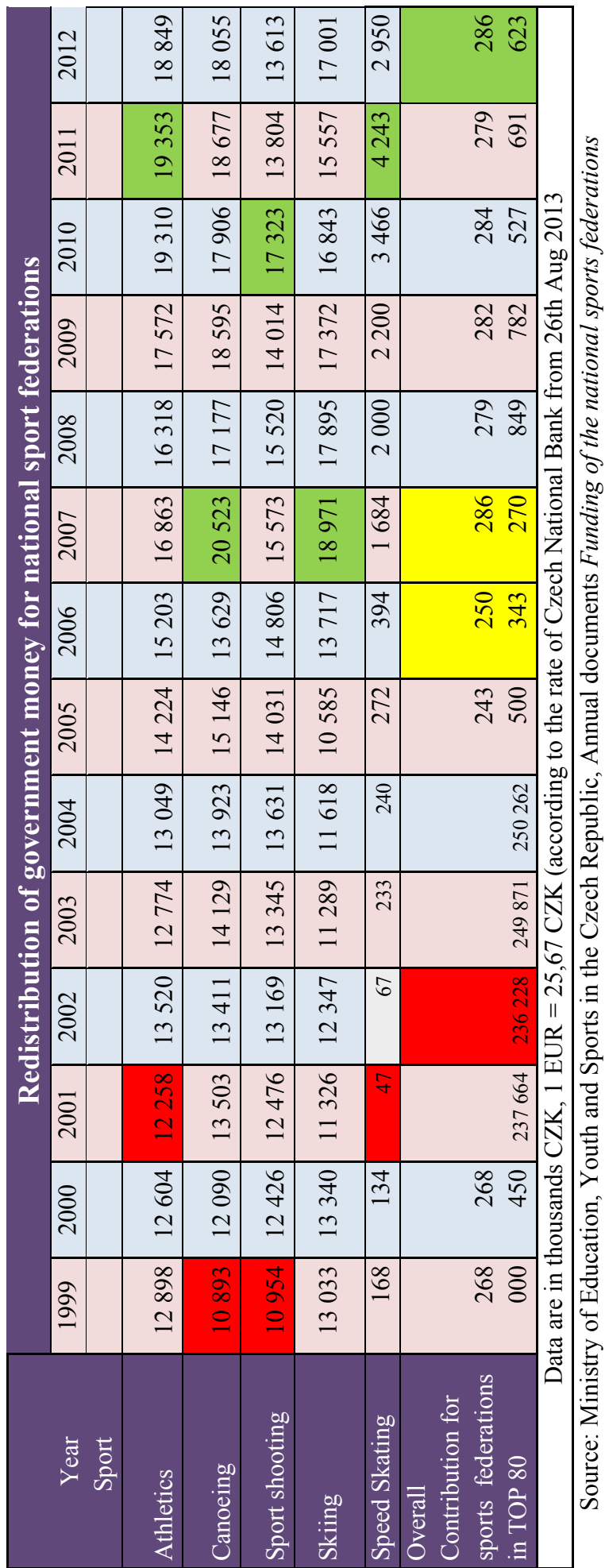


In the development of the overall contribution the year 2007 is important because this year records significant increase from 250 million CZK 286 million CZK) of overall government money that flows into sports federations. After this year overall contributions remained stable. That may be why the highest sums of support for particular sports are in this year or later. The importance of particular contribution on supported group is evident in the case of speed skating: In 2001 speed skating was on the 65th position in TOP Ranking in supported group 3 and gained only 47 thousands CZK while in 2011 speed skating was found on the 17th position in TOP Ranking in supported group 2 and gained only 47 thousands CZK while in 2011 speed skating was found on the 17th position in TOP Ranking in supported group 2 and gained 4243 thousands CZK contribution.

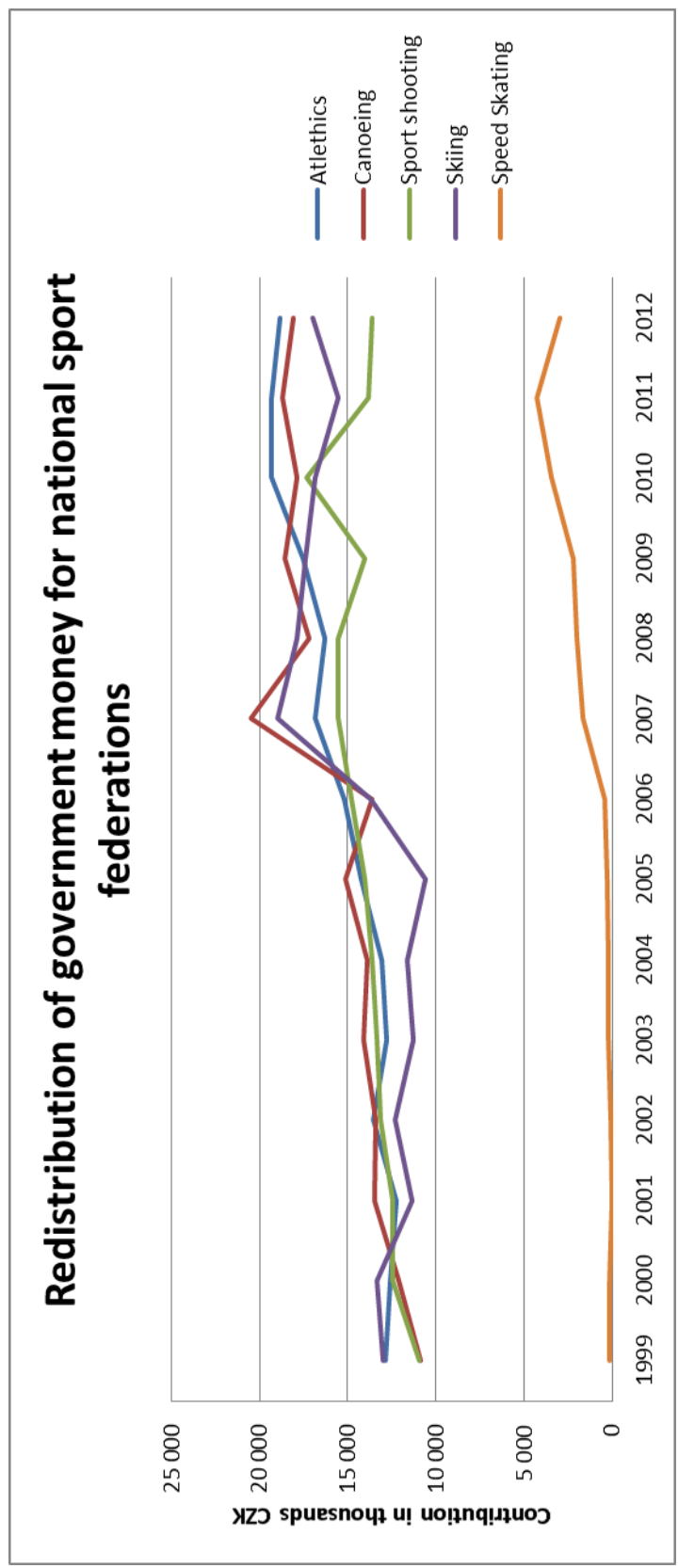

Picture 1: Redistribution of government money for national sport federations

Although athletics are long-term in the top of TOP Ranking of Czech sport federations the contributions are the highest since 2010. It is due to the fact that overall contribution consists of two other components: preparation of athletes and participation on international sporting events is more expensive in case of other 
sports. Common for all sports federations is increase of the contributions in year 2007. The reasons were mentioned above. Each sport federation will be analyzed separately further.

\section{Standings of sport federations in TOP Ranking}

Based on points gained in TOP ranking, sports were classified into following supported groups:

Table 2: Position of sports in TOP ranking and supported groups

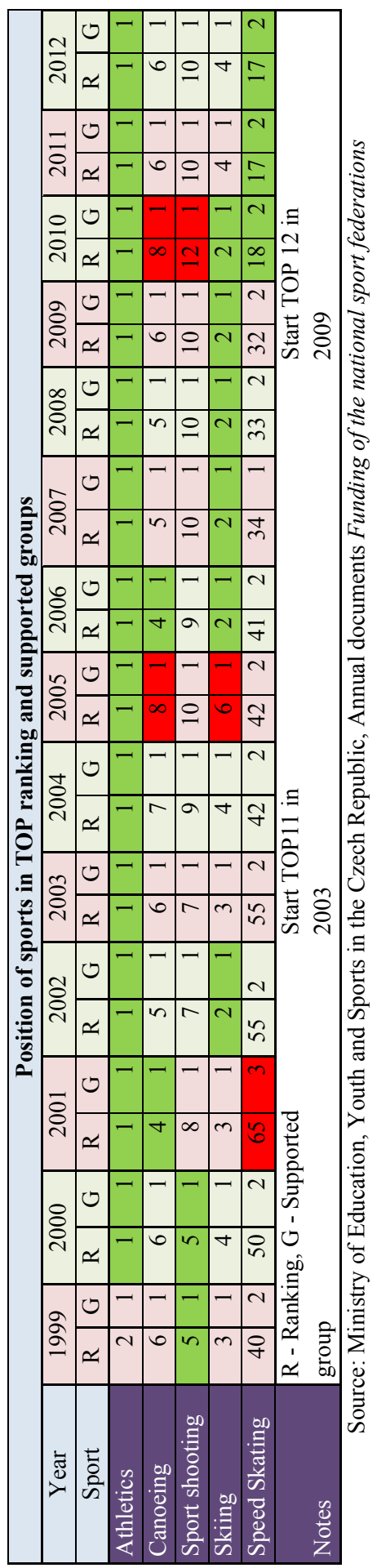


This table is very important as for the contribution of government money for national teams of each sport federation. According to the rules, the support is differentiated. Therefore it is important to be placed in the highest group of support (to remain a prominent sport branch) - otherwise it would have effect of strong drop in the government contribution for particular sport federation. When we analyze particular sports we arrive into conclusion that athletics has very stable position in this ranking (with the exception of one year it is the most important sport branch in the Czech Republic). Two other sport branches have also very stable position - skiing and canoeing. Sport shooting has weaker position. In 2010 it was found on the 12th position. Only thanks to the enlargement of most preferred sports in the Czech Republic in 2009, sport shooting remained in the first supported group. After London Olympics it will be challenge for sport shooting to stay within the prominent sport group in the Czech Republic. Speed skating is the most dynamic (out of the research sample) sport branch according to the movement in the TOP ranking. Speed skating was in the second category from 1999 to 2000. In 2001 it dropped into third category. Then it was slightly improving to year 2003. And after beginning active racing career in adult category of Martina Sablikova it went straightly upward and recently speed skating is on the 17 th place.

\section{Athletics}

The following picture shows financial contribution for Czech national team in athletics:

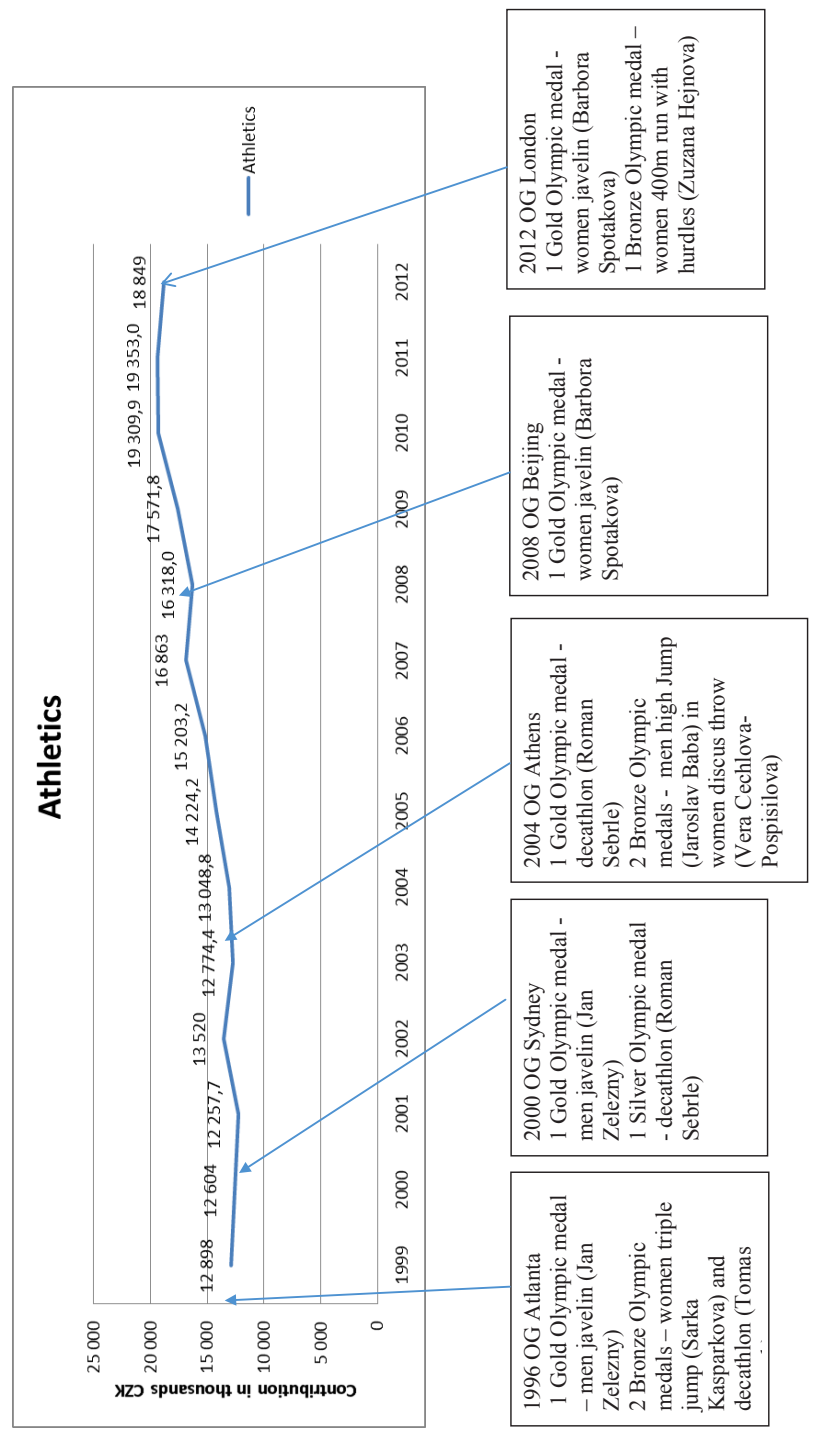

Picture 2: Redistribution of government money for athletics for the national team 
As shown, athletics is successful sport in gaining medals for the Czech Olympic team. In every summer Olympic Games from 1996 to 2012 at least one gold medal was earned by Czech athletes. That means that in the long-time perspective, this sport finds itself on the top of prominent sports (supported group 1) in the Czech Republic according to the TOP Ranking.

Contributions throughout the last decade are very stable and although at the Olympic Games 2008 in Beijing there was only one gold Olympic medal won the overall contributions for athletic federation in order to represent the Czech Republic has a rising trend.

\section{Canoeing}

The following picture shows financial contribution for Czech national team in canoeing:

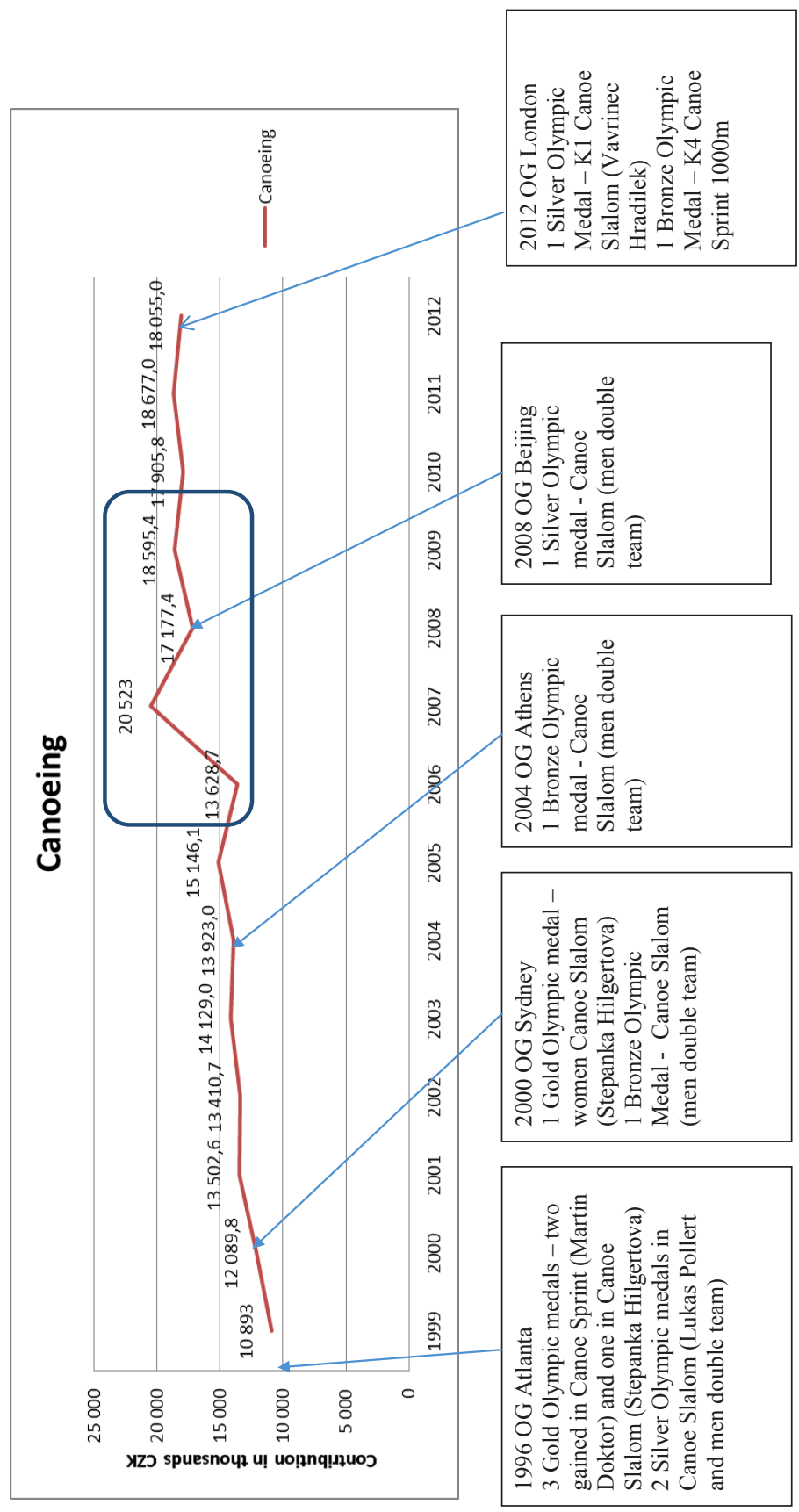

Picture 2: Redistribution of public money for canoeing for national team 
In canoeing the Czech national team was successful more in the 1996 and 2000 Summer Olympic Games than in 2004 and 2008 Olympics where Czech athletes didn't gain any gold Olympic medal. However, canoeing still remained in supported group 1 according to the TOP Ranking. Despite of the relative failure at Olympics 2004 and 2008 the main positive development of contribution for the federation of Canoeing came after year 2006 (from 13 628,7 thousands CZK in 2006 to 20523 thousands CZK in 2007 - more than $50 \%$ increase). This effect is not caused by the results at the Olympics. It was caused partially by success at World Championship. In 2006 the ICF Canoe Slalom World Championship was held in Prague and Czech athletes gained 5 medals (two titles of world champions) and gained the second place after French national team which earned four titles of world champions. The second and even more important reason was that the contribution for participation of Czech athletes in international sporting events rose in 2007 in general as well - mainly because the world championship took place in Brazil. And the participation of Czech team at this event was very costly. 


\section{Sport shooting}

Contribution for Czech sport shooting federation is captured in the following picture:

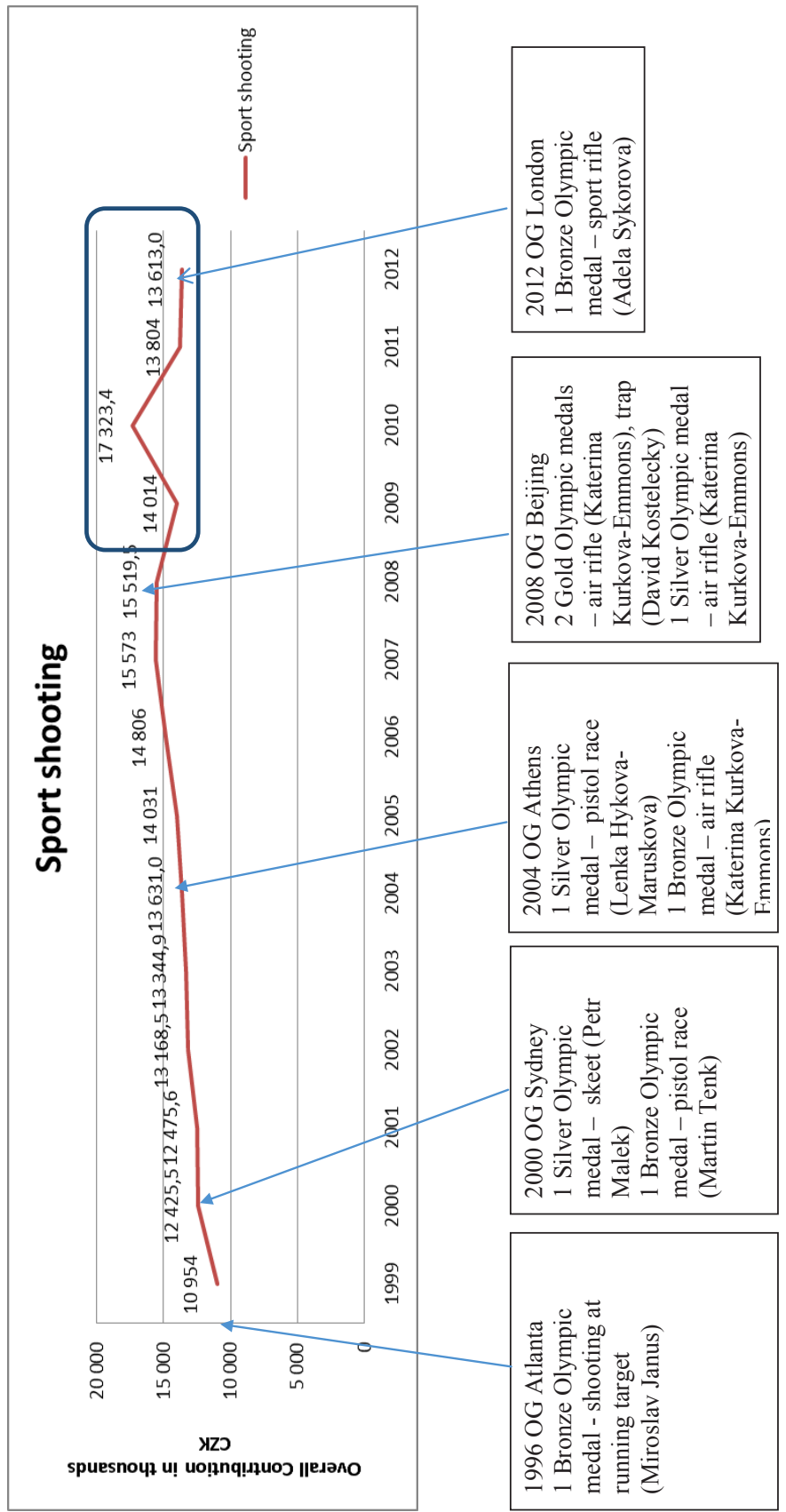

Picture 3: Redistribution of public money for sport shooting for national team

Sport shooting is the sport where Czech athletes are traditionally successful at the Olympics. In the relevant period the Czech Republic achieved better and better results. Contribution for the national team was stable. However, after achieving the biggest success at the Olympics at Beijing in 2008 (two gold and one silver Olympic medals) the sum of government money for sport shooting decreased in 2009. The main reason of the decline is in 2010 the contribution dramatically increased so the reduction from previous year was surpassed and overall contribution was the highest in the history. The main reason of the increase laid in contribution to support participation at international sporting events (World Championship in Munich). Sport shooting must be 
aware of depression in supported group according to the TOP Ranking. Both the fact that in 2012 it was on 10th position and only one bronze Olympic medal from London 2012 don't give better prospects for future years.

\section{Skiing}

Contribution for Czech National team in skiing is captured in the following picture:

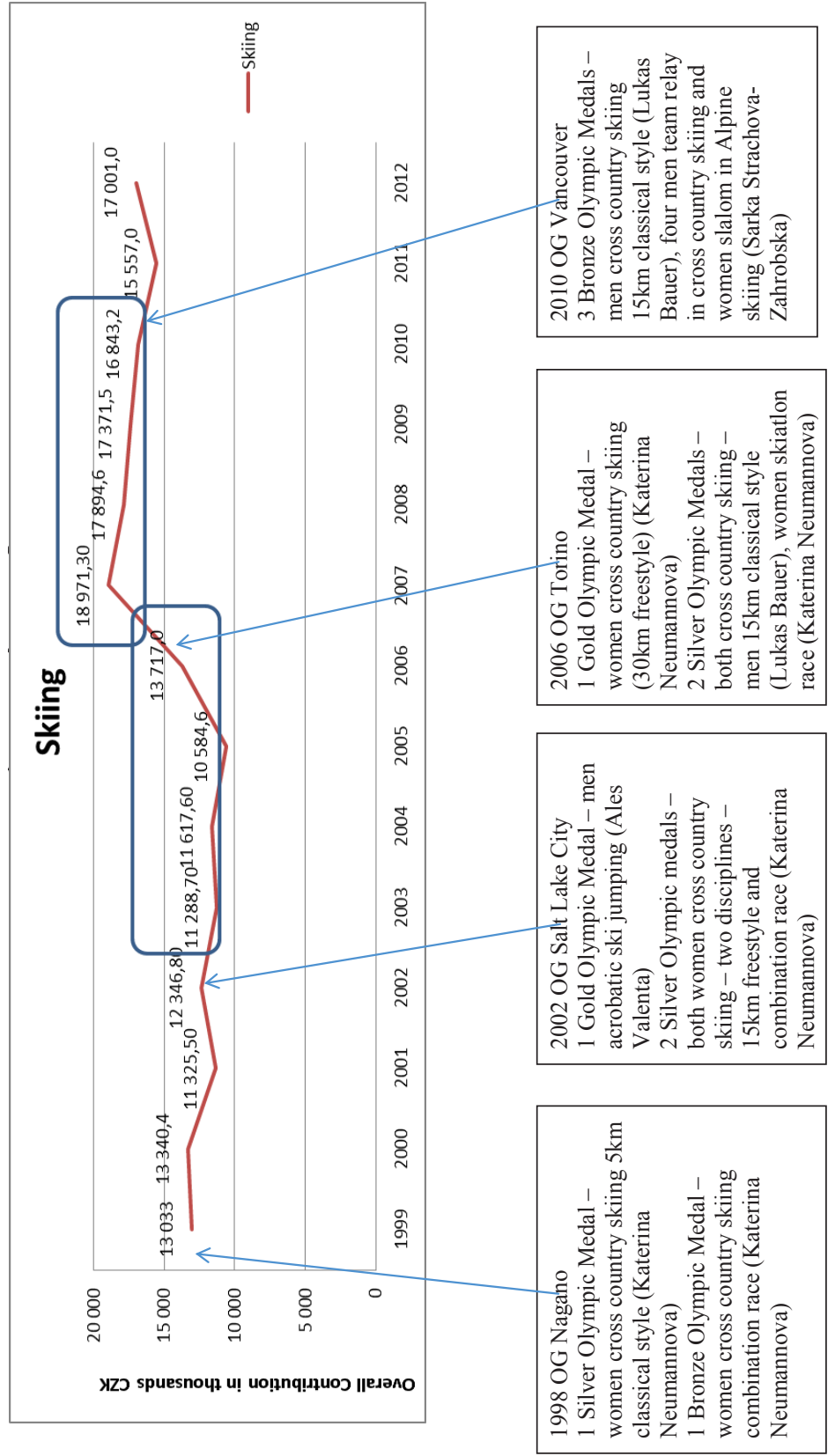

Picture 4: Redistribution of public money for skiing for national team

In skiing there is one main problem for finance analyses: within the skiing federation (both FIS - International Skiing Federation and SLČR - Czech National Skiing Federation) there are lot of disciplines - cross country skiing, Alpine skiing, Nordic Combined skiing, Ski jumping, Freestyle skiing, Snowboarding and other nonOlympic sports. There could be analyzed redistribution into particular sports in skiing. Skiing is high ranked sport in TOP Ranking throughout the investigated period. As for the overall contributions we can see that after successful Olympics 2002 in Salt Lake City ( 1 gold and 2 silver Olympic medals) there is significant decrease 
in contribution to the Czech national skiing team but after 2005 year the overall contribution rises. Although in Olympic Games 2006 in Torino Czech team had the same medal gains as in 2002 in Salt Lake City the contributions for the ski federation grew significantly. The peak was in 2007. The main reasons of such high growth lay in success of Czech athletes in world cups and world championships - Jakub Janda won world cup in ski jumping in 2006, Sarka Zahrobska in women's slalom at world championships in alpine skiing 2007, Lukas Bauer won world cup of cross country skiing in 2008 etc.

Comparison of the two periods with equal Olympic medal gains:

2003-2006

The first period after Olympic Games in Salt Lake City 2002 (2003-2006) the average contribution to skiing federation was 11802 thousands CZK (4,75\% of overall contribution to sports federations).

2007-2011

The second period after Olympic Games in Torino 2006 (2007-2010) the average contribution to skiing federation was 17770 thousands CZK (6,27 \% of overall contribution to sports federations).

\section{Speed skating}

Contribution for Czech National team in speed skating is captured in following picture:

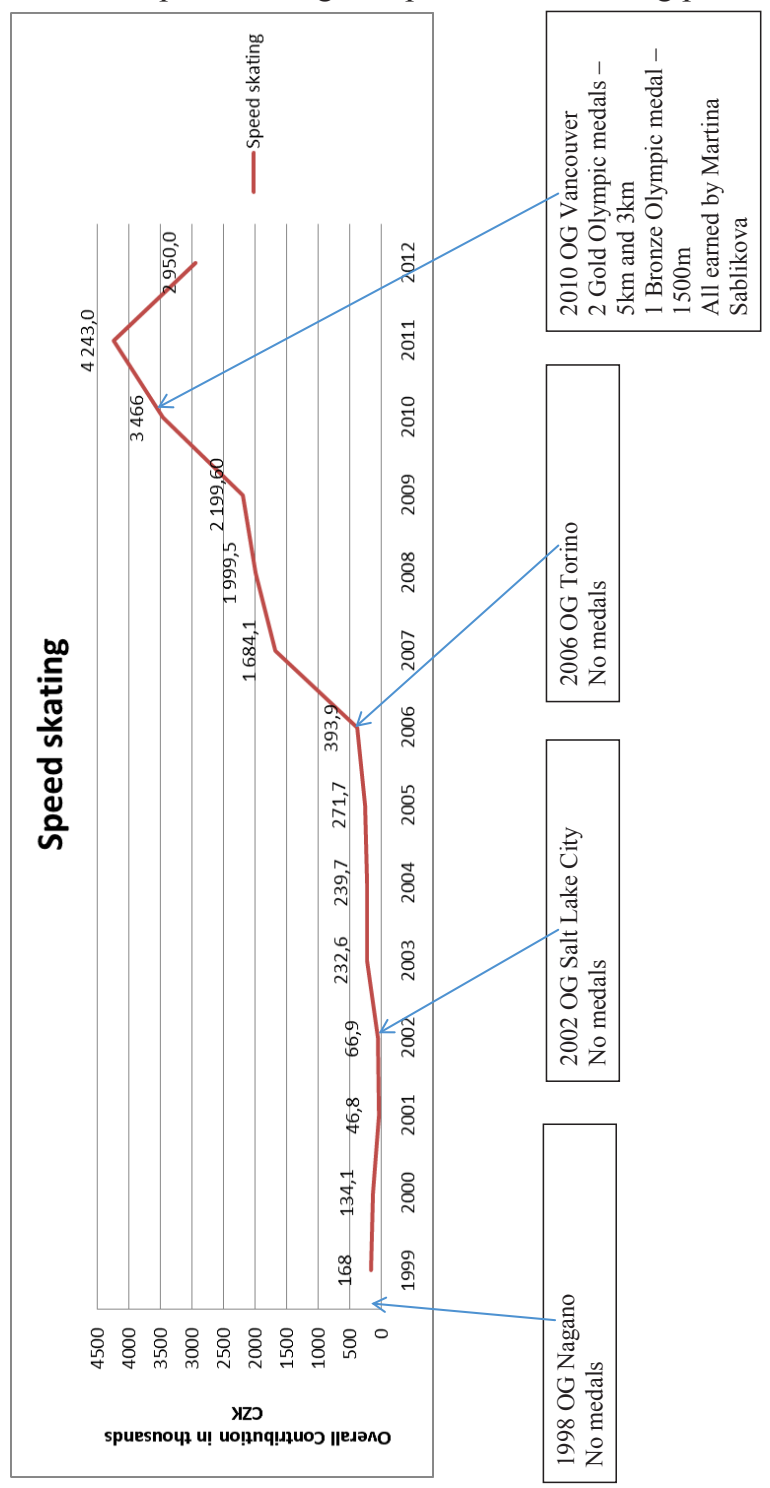

Picture 5: Redistribution of public money for speed skating for national team 
Speed skating is the sport where sport success brought substantial money for national speed skating federation in the Czech Republic. Although Martina Sablikova didn't win any medal in Olympics 2006 in Torino she came fourth at $5000 \mathrm{~m}$ race and seventh at $3000 \mathrm{~m}$ race. From 2007 to 2010 she won many world championship titles in $3000 \mathrm{~m}$ and $5000 \mathrm{~m}$ distance races and in all-round race as well. From 2006 year the contributions for the Czech speed skating federation were rising very fast. In 2010 there was the contribution of 3466 thousands CZK compared to 272 thousands CZK in 2005 - it is more than 12 times higher only in five years period. In 2011 after successful Olympic year 2010 contribution for raised to 4243 thousands CZK which is maximum in investigated period. The main reason of growth of the contribution lays in sporting success of Martina Sablikova at Olympics. In the TOP Ranking speed skating holds consequently two years 17 th place. It is very likely that speed skating will not make it into the supported group 1 in TOP Ranking but just now the evidence can be seen that success at the Olympic Games can affect the financing of sport federations.

\section{CONCLUSIONS}

What is the value of gold Olympic medal in the Czech Republic? Does gold Olympic medal affect funding of sports federations in the Czech Republic? These questions were asked at the beginning of the research. The article provides information about Czech Olympic medals from 1996 to 2012 at summer and winter Olympic Games in the "History of Czech Medals at Olympic Games from 1996 to 2012". The model of redistribution of government money that should be used for the representation of Czech Republic at the international sporting events with specific calculation and comparing of sport federations called TOP Ranking are given in the „Redistribution of Government Money for National Sport Federations - Model”. Evidence and analysis of financing sport federations of athletics, canoeing, sport shooting, skiing and speed skating is finally presented in "Redistribution of Government Money for National Sport Federations - Evidence and Analysis".

What are the results? Most important factor that influences the amount of contribution of government money for representation purposes of the Czech Republic that flows into sport federations is the position of the sport federation in the particular supported group according to the the TOP Ranking. The higher supported group finds itself in the ranking, the higher the contribution is since in the higher supported groups larger amounts of money are redistributed. The evidence can be taken from speed skating: in 2001 speed skating was on the 65th position in TOP Ranking in the supported group 3 and gained only 47 thousands CZK while in 2011 speed skating was on the 17th position in TOP Ranking in supported group 2 and gained 4230 thousands CZK contribution.

The second important fact remains that sporting successes of the athletes in the Olympics in single sports branches are very important related to the amount of contribution because due to the model it is $50 \%$ of total government contribution to sport federations. At the same time, sporting results at other international competitions such as world championships and world cups are also important what can be observed as in the case of skiing periods: the first period from 2003 to 2006 in comparison with the second period from 2007 to 2010.

The third important finding is that at some occasions the particular amount of the state contribution (or in yearly change) to the sport federation is not affected by sporting success but by the amount of contribution that should be used on participation of athletes at international sporting events. This fact can be supported by evidence from canoeing (year 2007) or from sport shooting (year 2010).

Finally gold Olympic medals have significantly positive effect on the government contribution for particular sport federation for several reasons: The first reason is that it takes next three years to the calculation of TOP Ranking of sport federations. Due to the medal the single sports branch can remain in the higher supported group. The second reason is that the gold Olympic medal means usually more places for athletes to compete: they can start at world cups and world championships in consequent seasons and that affects both amount of money intended for preparation of athletes representing the Czech Republic and amount of money for participation of athletes at the respective international sporting event. Because of the complexity of the model and number of sport federations that compete each other for higher share from one government budget it is impossible to quantify the isolated value of gold Olympic medal in general. 


\section{REFERENCES}

Andreff, W, Szymanski, S (2006). Sport and Financing, Handbook of the Economics of Sport, (1st ed.), Cheltenham, Edward Elgar Publishing Limited.

Czech Olympic Committee, List of Olympic medals gained by the Czech Republic, available online at www. olympic.cz

Hindls, R., \& Hronová, S., \& Seger, J., \& Fischer, J. (2007) Statistika pro ekonomy (8th ed.). Prague, Professional Publishing.

Ministry of Education, Youth and Sports in the Czech Republic, Annual documents The principles of the program for sport federation government support, available online at www.msmt.cz

Ministry of Education, Youth and Sports in the Czech Republic, Annual documents Funding of the national sports federations, available online at www.msmt.cz

Novotný, J., et al. (2011). Sport v ekonomice, $1^{\text {st }}$ edition, Praha, Wolters Kluwer 